INTERNATIONAL JOURN AL OF RESEARCHES IN BIOSCIENCES, AGRICULTURE AND TECHNOLOGY (c) VISHWASHANTI MULTIPURPOSE SOCIETY (Global Peace Multipurpose Socie ty) R. No. MH-659/13 (N) www.vmsindia.org

\title{
STATUS OF WATER QUALITY OF KAPILESHWAR DAM, ASHTI, DIST- WARDHA WITH REFERENCE TO PLANKTON DIVERSITY
}

\author{
P. J. Awate ${ }^{1}$ and M. R. Kakpure ${ }^{2}$ \\ 1 Departme nt of Zoology, Department of Botany, \\ 2S.M.D. Bharti Mahavidyalaya, Arni Dist-Yavatmal. 445103 (Maharashtra). \\ mr.prashantawate@gmail.com
}

\begin{abstract}
The present study objectively conducted to analysis the physico-chemical parameters and planktonic diversity of Kapileshwar dam. The study area was divided into five sampling stations to cover the whole dam area comprehensively during the June 2013 to July 2014.The physico-chemical parameters were observed Temperature, Transparency, $\mathrm{pH}$, Turbidity, Total Dissolved Solid, Total alkalinity DO, Total hardness, Nitrate Sulphate and Phosphate during the study. Water temperature exhibited feeble positive correlation with zooplankton. Transparency played an important role in flourishing population of phytoplankton as it established a positive correlation at $1 \%$ level of significance $(\mathrm{r}=0.729)$. The dissolved oxygen in water of the dam ranged from $5.00 \mathrm{mg} / 1$ to $9.10 \mathrm{mg} / 1$ at station I and II characterized as good level of water body. Nutrients like nitrates and phosphate present in the water body we re found in the permissible limits as prescribed by WHO, BIS for drinking water quality which confirm that the water is unpolluted and safe for drinking purposes. At present the Kapileshwar dam is of mesotrophic nature.

Keyw ords: Physico-chemical parameters, Kapileshwar dam, Plankton and Mesotrophic.
\end{abstract}

\section{Introduction}

The water of Kapiles hwar dam is utilized for drinking, irrigation and for fisheries activity. It is necessary that the quality of water should be checked periodically because due to use of contaminated water biotic fauna may suffer from a varie ty of water born diseases Sunkund and Patil (2004). In recent times limnological studies are often related to fisheries, biodiversity conservation, pollution assessment and rejuvenation of degraded inland freshwater ecosystems (Arlinghaus et al., 2008). Zooplankton diversity is one of the most important ecological parame ters in water quality assessment. In many areas, the ecological impacts from human activities will far exceed the impacts from climate change, Scholze et al., (2006) have worked on a climate-change risk analysis for world ecosystems, Islam (2007) in a pond of Rajshahi University, has investigated the effects of abiotic parameters on the variations of zooplankton population. Zooplankton is good indicator of the changes in water quality because they are strongly affected by environmental conditions and respond. Nelson etal.,(2009)carried out a detailed study on the combined effects of urbanization and climate change on stream ecosystems: from impacts to management options. Similarly, Durance and Ormerod (2009) have investigated existing trends in water quality and the consequent discharge confound long - term warming effects on river macroinvertebrates. The study of plankton and physico-chemical property of water was carried out by various people like Mishra and Saksena (1991), Kuashik and Saksena (1995). Patel et al., (2013), Vasanthkumar and Vijay Kumar (2011), Garg et al., (2010). The present study was aimed to evaluate water quality and occurrence of zooplankton and phytoplankton with reference to physico-chemical parameters in a Kapiles hwar dam.

\section{Material and Methods}

The Kapileshwar dam is a man made re se rvoir constructed on a local nalla. It is at 780-17'-00" E longitude and 200-12'-00"N .The length of dam is $589 \mathrm{mtrs}$. and 7.31 meters high with a catchment area of 6.68 square $\mathrm{km}$ situated near Ashti Tahsil of Wardha District.Gross storage capacity of the rese rvoir is about $1.720 \mathrm{Mm}^{3}$.The study area was divided into 5 sampling sites .Water samples were collected regularly on monthly basis in between 8 a.m. to 10 a.m. Water $\mathrm{pH}, \mathrm{DO}$, and TDS observed at sampling site using water analysis kit(Systronic make) while other abiotic components were analyzed at laboratory condition using the method prescribed by APHA(1989).

\section{Result and Discussion}

It is fact that mainte nance of healthy aquatic ecosyste $m$ is dependent on the physicochemical properties of water. Station wise mean values of physico-chemical parameters are summarized in Table 1. 


\section{Water Temperature (WT)}

Temperature is one of the most important ecological factors, which controls the physiological behavior and distribution of organisms. In present study, lowest value of water temperature found in January $19^{\circ} \mathrm{C}$ and highest in Jun $31.10^{\circ} \mathrm{C}$ with the mean values $26.11^{\circ} \mathrm{C}$.that shows the optimum ranged for growth of aquatic fauna and flora. This result agrees with the reported by Swaranlatha and Rai (1998) in Banjara Lake. Salve(2006)also reported similar trends in Wan Prakalp rese rvoir, Nagpur.

pH

$\mathrm{pH}$ regulated most of biological processes and bio-chemical reactions. $\mathrm{pH}$ value ranged from minimum 6.05 to maximum 7.48 at station-I. The $\mathrm{pH}$ of water tends towards alkaline nature.Minimum $\mathrm{pH}$ was found in the month of April(summer) and reached to the maximum in the month of December (winter).This is in agreement with the findings of Manjare et al.,(2010) who studied the Vadgaon tank of Kolhapur.Mean and range $\mathrm{pH}$ value of all the five stations observed was $6.98 \pm 0.10$.

\section{Transparency}

Fresh water body in the present investigation showed no typical tre nd.Average mean value of water transparency evaluated is $47.68 \mathrm{~cm}$. The lower values of transparency during rainy season may be attributed due to the rains which might have brought silt and mud from the catchment area making the water turbid. This is in the conformation with the observation made by Zafar (1966); Kaur et al., (2008). Mwara, (2006) also observed low transparency during rainy season in manmade rese rvoirs in Kenya.It was found higher in the summer season which might be due to suspended particles accumulated during summer months or may be attributed to human activity like washing and bathing.Jaybhaye (2009) also reported similar trends in Parola dam of Hingoli dis trict.

\section{Total dissolved solids (TDS)}

TDS is measure of all the dissolved substances, both organic and inorganic in water. Higher TDS attributes to high dissolved and suspended particles in to the water.At station-I the total dissolved solid was found higher $400 \mathrm{mg} / 1$ with the mean value considering all five station was $315.71 \mathrm{mg} / 1$. It is in the range of permissible limit. Similar results were also reported by Chaturbhuj et. al.,(2004) in the Jamwa Ramgarh Lake, Jaipur.

\section{Turbidity}

The wate $r$ was less turbid as observed during study period. Monsoon months particularly showed turbid water which is attributed to the surface runoff in the rainy season from the catchment area; recently Manjare et.al.,(2010) have reported higher turbidity in summer season. Average mean turbidity values of the entire sampling site calculated to 39.95 NTU.

\section{Total alkalinity}

Total alkalinity of water is the quality of water and kinds of components present in water such as bicarbonate, carbonate and hydroxide. Total alkalinity was in the ranged from $106 \mathrm{mg} / 1$ to $330 \mathrm{mg} / 1$ at sampling station -II and sampling station-V (Table-1) respectively. The maximum value recorded in the month of January(winter) and minimum in the month of August(monsoon).The alkaline water was found productive.Spence (1967) classified the lake into three categories based on alkalinity. On the basis of this classification, Kapileshwar dam considered as a nutrient rich dam.

\section{Dissolved oxygen(DO)}

Dis solved oxygen is an important limnological parameter indicating level of water quality , organic production and reflects the physical, biological processes prevailing in the dam water. It ranged was $5.00 \mathrm{mg} / 1$ to $9.10 \mathrm{mg} / 1$. The level of DO was found less during the month of may(summer). This is because of the low solubility of gases at high temperature Hynes,(1978); similarly during summer water volume also decreased and became more concentrated with the pollutants, Decreased DO in summer correlates with the higher solubility of oxygen at lower temperature. This is in agreement with the recent findings of Garg et al.,(2010) who found that dissolved oxygen was less during summer season. Average DO in the present study also exceeded the limit of $5 \mathrm{mg} / 1$ as per European Environmental Commission Chapman (1997) and mean value observed in the present investigation was $7.91 \mathrm{mg} / 1$. Therefore, it can be concluded that water is safe for human consumption.

\section{Total hardness}

The hardness of wate $r$ is mainly governed by the content of calcium and magnesium which largely combine with bicarbonates \& carbonates (temporary hardness) and with sulphate, chlorides and other anions of minerals (permanent hardness).In the present study,mean value of total hardness of five different stations was observed as $127.17 \mathrm{mg} / 1$ . The minimum and maximum evaluated was 86 $\mathrm{mg} / 1$ and $226 \mathrm{mg} / 1$ respectively. It was found in permissible limit.

\section{Nitrates}

Nitrate is basic nutrient, which is determined the productivity of lake. In the fresh water nitrate content is meager. In the present study the average values of nitrate of all the sampling stations were observed to be $0.48 \mathrm{mg} / 1$. the re 
was no seasonal trend in the concentration of nitrates and minimum concentration was found $0.19 \mathrm{mg} / 1$ at station-I while maximum $0.87 \mathrm{mg} / 1$ at station-IV.Nitrates were estimated more in winter season. This is in agreement with the findings of Islam(2007).

\section{Sulphate}

Most of the sulphate ions are probably derived from the solution of calcium \& magnesium ions. Sulphate is naturally occurring ion found in all types of water and wide ranges in nature. Occurrence of sulphate in water is due to influx of runoff and leaching process. The average mean of water sulphate content was found to be
$12.46 \mathrm{mg} / 1$ which is in permissible limit. Bhagat (2008) have also observed minimum sulphate content in Ambadi dam, near Akot Dt.Akola.

\section{Phosphate}

The lower and higher values fluctuated from $0.02 \mathrm{mg} / 1$ to $0.60 \mathrm{mg} / 1$ at station- $\mathrm{V}$ and stationII respectively. Ave rage mean of all the five stations calculated $0.25 \mathrm{mg} / 1$. Winter months contribute higher concentration as compared to monsoon and summer seasons. Higher values may be due to accumulation of surface agricultural runoff and washing activities that contributed to the inorganic phosphate contents.

Table 1 : Showing station wise mean values of Kapileshwar dam during June 2013 to July 2014

\begin{tabular}{|l|l|l|l|l|l|}
\hline \multirow{2}{*}{ Parame ters } & \multicolumn{5}{|l}{ Sampling stations } \\
\cline { 2 - 6 } & I & II & III & IV & V \\
\hline Water temperature $\left({ }^{0} \mathrm{c}\right)$ & 25.82 & 25.36 & 25.66 & 26.11 & 25.76 \\
Transparency(cm) & 43.95 & 70.64 & 61.29 & 27.11 & 25.76 \\
\hline Total Dissolved Solid $(\mathrm{mg} / 1)$ & 251.43 & 264.29 & 260.00 & 315.71 & 282.86 \\
\hline pH & 6.95 & 6.93 & 6.82 & 6.98 & 7.05 \\
\hline Turbidity( NTU) & 41.57 & 32.40 & 38.17 & 44.40 & 43.20 \\
\hline Total alkalinity $(\mathrm{mg} / 1)$ & 153.00 & 163.57 & 158.14 & 185.14 & 208.29 \\
\hline DO $(\mathrm{mg} / 1)$ & 7.41 & 6.47 & 6.20 & 7.91 & 7.12 \\
\hline Total Hardness $(\mathrm{mg} / 1)$ & 128.57 & 128.57 & 126.29 & 117.43 & 135.00 \\
Nitrate $(\mathrm{mg} / 1)$ & 0.43 & 0.45 & 0.49 & 0.49 & 0.52 \\
\hline Sulphate $(\mathrm{mg} / 1)$ & 9.68 & 9.27 & 13.69 & 19.89 & 9.75 \\
\hline Phosphate $(\mathrm{mg} / 1)$ & 0.31 & 0.29 & 0.16 & 0.32 & 0.18 \\
\hline
\end{tabular}

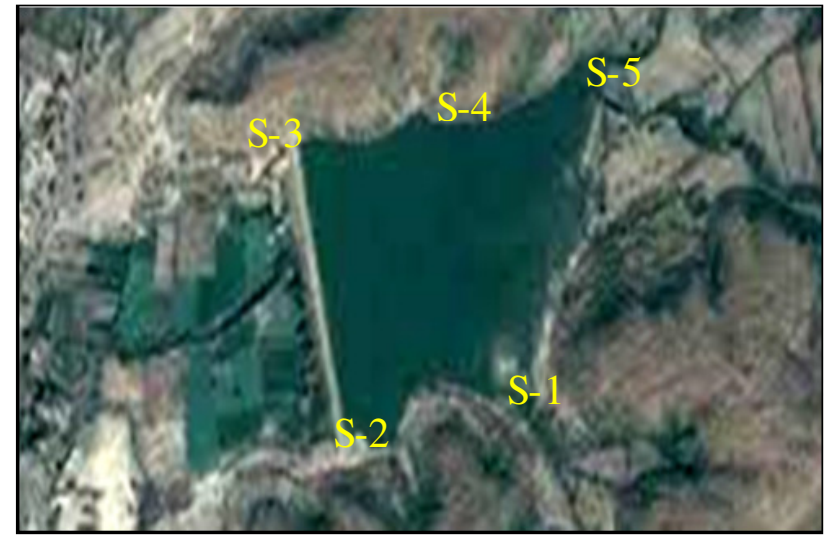

S-1:-Sampling station 1

S-2:-Sampling station 2

S-3:-Sampling station 3

S-4:-Sampling station 4

S-5:-Sampling station 5

Figure:-Map of Study area (Kapileshwar Dam of Ashti) 


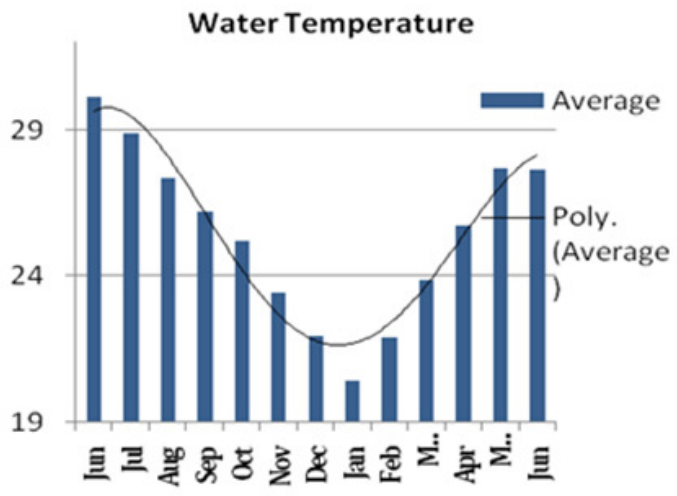

Figure 1

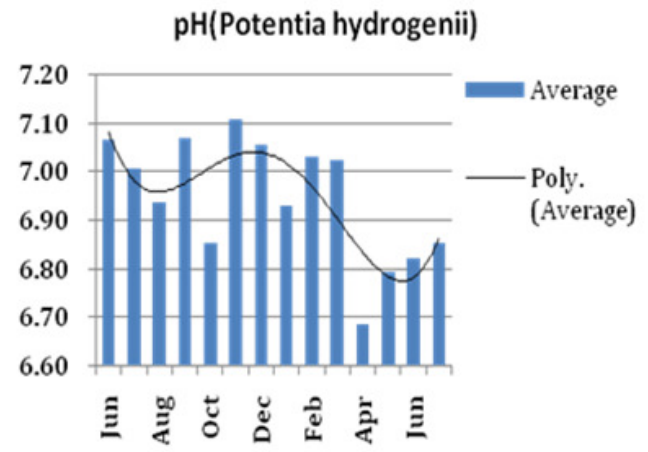

Figure 2

\section{Transparency(NTU)}

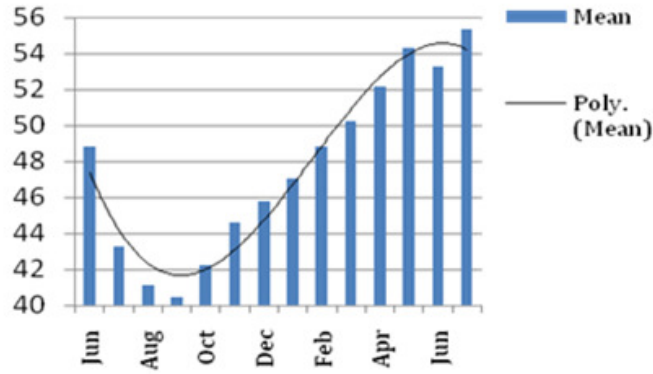

Figure 3
Turbidity(NTU)

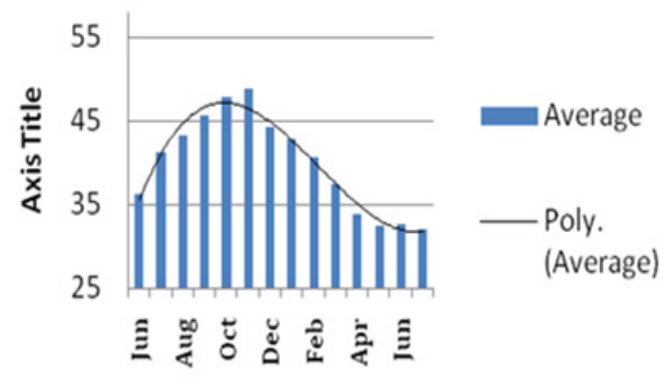

Figure 4

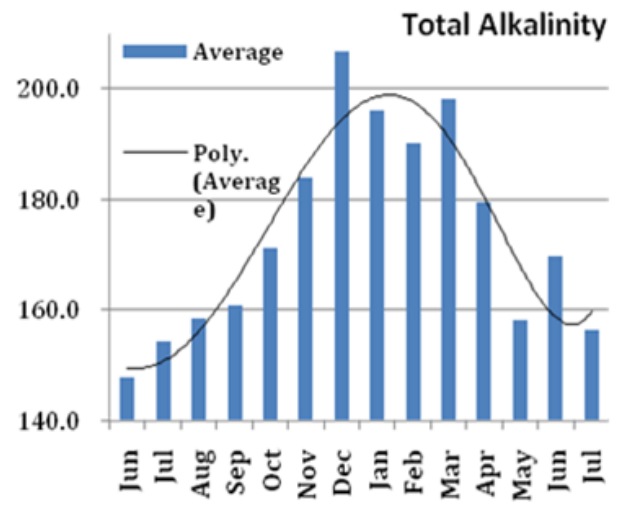

Figure 5

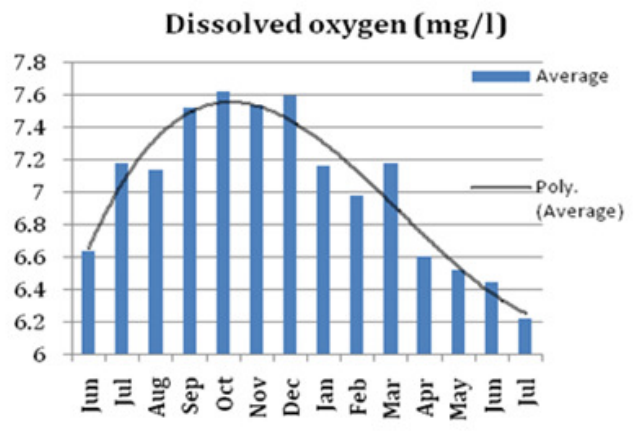

Figure 6

Figure (1-6):Graphical representations of mean of physico-chemical parameters of Kapileshwar dam during June 2013 to July 2014. 


\section{Conclusion}

The pollution indicators phytoplankton and zooplankton we re less in number at all the stations similarly As no industrialization has taken place in the surrounding areas, menace of effluent discharge and subsequent pollution is not evident in the dam. Abiotic components are found in the safe limit which confirms that the water is safe for drinking and also for healthy fish culture. The present status of water body is mesotrophic and unpolluted hence, the water can be utilized for irrigation, drinking and fis hery activities.

\section{References}

APHA (1989) Standard methods for Examination of water and waste water, $2^{\text {nd }}$ Edn.

Arlinghaus, R., Johnson, B.M., and Wolter, C. (2008) The past, present and future role of limnology in freshwater fisheries science... Int. Rev. of Hydrobio., 93:541-549.

Bhagat,V.B.(2008) Planktonic biodiversity of Ambadi Dam, near Akot Dt. Akola.(Ph.D thesis)

Chapman D (1997) Water quality assessment, $2^{\text {nd }}$ Edn published by E\&FN Spon. Chapman \& Hall,2-6 Boundary,Row London,U.K.

Chaturbhuj, M., Sisodia, R., Kulshreshtha, M., and Bhatia, A.L., (2004) A Case study of the Jamwa ramgarrh we tland with special reference to physico-chemial properties of water and its environs, Department of Zoology, University of Rajasthan, Jaipur, India ,J. of Hydrobio, 16.

Durance I.and Ormerod S.J. (2009) Trends in water quality and discharge confound long-term warming effects on river macroinve rteb rates..Freshwater Bio., 54:388-405.

Garg,R.K. Rao,R.J. and Uchchariya, D., Shukla,G.and Saksena D.N. (2010) Seasonal variation in water quality and maior threats to Ramsagar reservoir India..Afr. J. Env.l Sci. and Tech.., Vol.4(2):061-076.

Hynes H.B. (1978) The biology of polluted water,Liverpool Uni.Press,Live rpool,2 00-204.

Islam S. N. (2007) Physico-chemical condition and occurance of some zooplankton in a pond of Rajshahi Uni.Res. J. Fish and Hydrobio.,2 (2):21 25.

Jaybhaye,V.M. (2009) Studies on Physicochemical parameters of Parol Dam in Hingoli District(MS), Shodh,Samiks ha \& Mulyankan Int. Res.J., Vol.2(9-10):44-46.

Kaur,R.,Minhas,P.S.,Jain,P.C.,Singh,P. and Dubey,D.S. (2008) Geo-spatial analysis of landwater resource degradation in two economically contrasting agricultural regions adjoining national capital territory (Delhi).Environmental
Monitoring \& Assessment,doi:10.1007/s10661008-0378-3.

Kaushik, S. and Saksena, D.N. (1995) Trophic status and rotifer fauna of certain water bodies in ce ntral India. J .Env. Bio. 16:283-291.

Manjare,S.A, Vhanalkar,S.A and D.V.Mulev(2010) Water quality assessment of Vadgaon tank of kolhapur with special refe rence to zooplankton, Int. J. Advance Biotech \& Res. Vol.1 (2),91-95.

Mishra, S.R. and Saksena, D.N. (1991) Pollutional ecology with reference to physicochemical characteristics of Morar (Kalpi) river, Gwalior (M.P.). In: Nalin K. Shastree (Ed.). Current trends in limnology. NarendraPublis hing.

Mwara, F. (2006) Some aspect of water quality characteristics in small shallow tropical man made reservoirs in Kenya. Afr. J.Sci and Tech., 7 (1): 82-96.

Nelson K.C., Palmer M.A.,Pizzuto J.E.(2009) Forecasting the combined effects of urbanization and climate change on stream ecosvste ms: from to management options, J.Applied Ecol., 154163.

Patel, V., Shukla, S.N. and Pandey, U. (2013) Studies on primary productivity with special Reference to their physicochemical status of Govindgarh Lake Rewa (M.P.), India. Int. J. Sci. Res., 2 (1 1):508-510.

Salve,B.S.and Hiware,C.J.(2006) Studies on water quality of Wan prakalp reservoir, Nagpur,near Parali Vaijnath DtBeed.J.Acqa.Biol. 22 1(2):113-117.

Scholze,M.,W. Knorr,N. Amell and I.C.Prentice (2006) A climate-change risk analys is for world ecosys tems: PIVAS 103, 13116-13120.

Spence, D.H.N., (1967) The zonation of plants in fresh water lakes .Adv. Ecol. Res..,12:37-125.

Sunkad B.N. and Patil H. S.(2004) Water quality assessment of fort of Belgaun(Karnataka) with special reference to zooplankton, JEnvi. Biol. 25(1), 99-102.

Swaranlatha, N., and Narsing Rai, A., (1998) Ecological studies of Baniara Lake with reference to water pollution. J. Env. Bio., 19(2):179-186.

Vasanth kumar, B. and Vijaykumar, K. (2011) Diurnal Variation of physico-chemical properties and primary productivity of phytoplankton in Bheema River. Recent Res. in Sci. and Tech., 3(4): 39-42.

Zafar, A.R., (1966) Limnology of Hussian sagar Lake, Hydrabad. India phykas, 5; 115-126. 